\title{
Objects in the Rear-View Mirror
}

\author{
Dan Kelly \\ H Block 6, Long Kesh
}

Twilight submitted to dusk as Joe lit a cigar and turned onto the slipway of the Boston Interstate. A light snow flurry brushed the dusty windscreen and soon became a proper snow shower. The radio played 'Merry Christmas everyone.' Joe laughed and sang along, tapping his fingers to the beat on the steering wheel.

Snow is falling all around, Children playing, having fun.

He felt good about himself. At 35 he was the number one salesman for 'Calco' fascia board house fronts, and had been so for the past three years, since knocking Kenny Spring off the number one spot. They were bitter rivals. Kenny, in Joe's eyes, was a sucker or a sad story who took no for an answer too easily. Only the best deserved the 'extras' the number one position brought: choice of new car, free holiday, and $10 \%$ higher cut of commission, not to mention the prestige. Joe had become very used to the attention, and the almost celebrity status associated with the position and he wasn't about to give that up lightly. The three newly-signed contracts in his briefcase would ensure that.

The sweeping wipers formed little ridges of snow on each side of the screen until blown away by the car's motion. The road was quiet, usually he preferred some traffic - lonely travellers of the night, unified by some unseen bond that lasted the short space of time they were visible to each other. Eventually, a set of headlights appeared in the magnified mirror. He noticed the sign at the bottom of the mirror; familiarity had made him forget it: 'Objects in the rear view mirror may appear closer than they are.'

As if on cue, the radio played Meatloaf singing, 'Objects in the rear view mirror.'

'Hold on a second,' Joe said to his stubbled refection. 'Is this guy psychic or what?' He was making connections between songs and events. 'Get a grip of yourself, Joe,' he smiled.

He was still smiling when the car behind started to overtake. As it drew level, the passenger slowly turned his head to look at Joe. They both passed an overhead light, and for a split second, it shone on the man's face. Joe slammed on the brakes forcing the car to skid on the slushy surface, it careered onto the hard shoulder. He stared hard in disbelief at the red tail lights disappearing into the swirling snow. The blood in his veins ran cold, he could almost hear the palpitations of his heart, his breathing quickened, white-knuckled hands felt weak. He lifted them off the steering wheel and covered his ashen face. 'It couldn't have been,' he said. 'I know it couldn't have been ... but it was ... It was George.' 
Joe's parents divorced when he was fifteen. While they were sorting out the messy details, he had stayed with his Uncle George and Aunt Mary on their small holdings farm in San Francisco. Although they were strict on both principles and morals, they were also fair, giving him the respect his own parents had not. He remained with them for the rest of a happy adolescence. The relationship turned sour however, when some years later George accused his nephew of shady dealings concerning lease holdings with the neighbouring farm. Joealways regretted not making his peace with his Aunt and Uncle before they died in an horrific car crash three years ago.

'Get a grip of yourself,' he repeated, slapping his face as if to waken himself. 'I need a break, that's it; I need a break. I've been on the road most of the year. As soon as I get these contracts registered, I'll take the family on a short New Year vacation. Bella has been nagging me about the hours anyway.' The radio still blared its music but now it began to bug him. He punched a button; any button. Some Reverend preached a sermon over the air waves, not really Joe's scene but somehow it was soothing to the ear.

'I'll rest here for a few minutes,' he thought. Still feeling a little weak, he lit a half Corona and inhaled heavily, laid his head on the headrest and blew a pall of grey smoke at the car's roof. It rolled along the padding like the plume of a miniature explosion. The voice on the radio faded to a smooth drone. His eyes relaxed, blinked, then closed.

'Have you earned money ignobly today?' the radio blared. His eyes jarred open. 'Yes you! I'm talking to you, if you're thinking about it, then I'm talking to you.' The Reverend was laying it on thick, Mississippi style. Joe blinked his eyes preparing to drive off.

'Give it back, redeem yourself and give it back.'

'Yeah yeah,' he said nonchalantly, then switched back to the music channel.

'The truth hurts, doesn't it Joe?' His head jerked towards the radio but it was playing music.

His eyes crept towards the mirror. The beam from a car's lights travelling in the opposite direction pierced the darkness in front. His eyes continued in the mirror's direction, almost afraid to look at it. In the flash of light caused by the passing car, he saw reflected in the mirror his uncle's unmistakable likeness, his salt and pepper beard the most distinguishing feature. Joe's whole being jumped with shock. He drew a sharp breath that pained his chest, he could hear his own pulse pounding in his ears. The cold shiver returned and tingled the length of his body from head, through spine, to his toes. He could feel a breath of cold air on his neck. Cautiously he edged his head to look over his shoulder, fearing what he was about to see, while nervous eyes watched what was now just an outline in the mirror. Then with quick jerk of head and body he turned to face the back seat. Nothing.

'There's nothing there,' he sighed with great relief.

Joe looked at his open shaking hands. His heart was still pounding. He rubbed his face as though he were washing. 'Jeez I'm cracking up,' he said. Once again he checked the mirror - nothing. He reached for the glove 
Journal of Prisoners on Prisons, Vol. 7, No. 1, 1996.

compartment, took out a bottle and swallowed two large slugs. His face was still cringed from the taste of raw whisky when the voice returned.

'What did I always tell you about drinking and driving?' He looked at the mirror once more. Still nothing. His face distorted as he put the bottle to his head again.

Ten miles were clocked before the voice returned in whispering tones. 'Give it back Joe.'

He was determined not to look, but disobeying eyes drew to the mirror like pin to magnet. 'Go Away,' he screamed. 'Go away and leave me alone, you're not there, go away.'

'How can I go away if I'm not here?' the voice asked.

'You're only my imagination, go away. I'm not going to think about you.'

'Call me what you will Joe, I'm here.' The voice hung in the stuffy, smokefilled air of the car.

'Go, leave me in peace, get out of my mind.'

'Give it back Joe, and I'll leave you in peace.'

'Give what back?'

'The contract you got tonight, and the other two in the case with it.' The flash of lights from an oncoming car blinded him for an instant. As his sight was returning he could have sworn he saw George finishing the sentence.

'Those people can't afford new house fronts.'

But when he checked again there was nothing. With a shake of his head he asked, 'Why am I talking to myself?'

He laughed aloud, a nervous laugh, and said, 'Joe man I think it's time to lay off the booze as well.'

'They can't afford it,' the voice whispered. Still there was no shadow, just a voice in his head.

'Of course they can afford it, they wouldn't have signed if they couldn't.' His ice blue eyes danced between mirror and road.

'You've had the Herrins' contract in your case from Monday. Would you like to see what happened to the Herrins, Joe?'

'No.'

'Look at the mirror Joe,' the hypnotic voice demanded.

'No!'

He tried not to look, but suddenly the mirror came to life, like a miniature television screen. Both the Herrins stood by the Christmas tree, embracing each other, both crying. The two-year-old twins played with the unfinished Christmas decorations.

'They weren't like that when I left them,' Joe protested. 'They weren't like that when I left them.'

'No they weren't,' the voice sighed. 'But Mr. Herrin hadn't lost his job then.'

'I can't help that, I'm only trying to do my job. Anyway I'm sure he'll find another job soon enough.'

'They can't afford it Joe.' 
His eyes moved nervously from mirror to road. Why was he torturing himself like this, he thought.

'Remember Mrs. Martin, Joe? You sweet-talked Mrs. Martin into signing, with promises of easy repayments, and the best after-sales services. You knew she was vulnerable, going through a bad patch with her husband. Then you, a sweet-talking, good-looking young man chat her up and she falls under your spell, but look at her now. Look at her,' the voice demanded.

Again his eyes drew unwillingly towards the picture. The Martins were in the middle of a heated argument, presents scattered across the living room floor. Then Mrs Martin was walking out of the house, carrying a suitcase in one hand, a child clung to the other, and two others followed in her wake. All in tears.

'I'm not a Goddamn marriage guidance counsellor,' Joe snapped. 'Their marriage was probably on the rocks anyway.'

'It was tough Joe, but they would have made it.' 'I want you to look at the Baker household six months from now.'

'NO! NO. I don't want to look at these stupid pictures.'

The mirror showed a picture of Mr. Baker, the man who had signed the contract that very night, sitting on his settee. Then the picture panned out to show him fitting a false hand to the stump of his right wrist.

'Mr. Baker was finding it hard to make the repayments, so he started moonlighting at a meat-processing factory at nights, but the two jobs were taking their toll on him. He fell asleep at one of the machines.'

'Look, you can't blame me for the world's wrongs. I'm sorry for Mr. Baker, but I'm sure the insurance will look after him.'

'Wrong Joe. You see he was moonlighting, and the insurance company, like your own, has fine print too.'

'You were the one who told me it's a competitive world, and to get out there and take my slice.'

The voice became harsh and loud. 'Not at other people's misery and expense. When I told you these things, you had a heart. Do you think you would have done as well without my help?'

'I got to this position on my own steam,' he barked, thumping the steering wheel.

'Did you? Did you now? And how long ago would that have been then?'

In a whispered stammer, he replied. 'Three ye ... Three years ago.'

'Since my accident ... All I ask you to do is to search your heart and give these people a chance. You have in your briefcase the opportunity to change their lives.'

His head slowly dropped from mirror to road. He drove in silence for some time. I must be going crazy, he thought to himself, hearing voices, seeing images.

Joe drove the next five miles recalling cases where families, through their ambition to improve their homes with a 'Calco' house front, had actually forfeited their mortgages when they couldn't keep up the repayments. The 
pictures of the three families appeared in his head time after time after time. His conscience gave him no rest. Eventually he relented. 'Okay,' he said solemnly. 'Okay, Monday morning I'll post the contracts back to them.' Suddenly, as if hitting a series of small ramps, the car shuddered and he felt drained and cold. He turned the heating to full, then noticed the sign for the turn off for his home town.

Bella greeted him at the door. After the family dinner, when kids were tucked into bed, he explained his experience on the motorway.

'Joe,' she said sternly. 'I didn't want to bring the subject up again, especially at this time of the year, but you know wh...'

'Don't start this all over again Bella, I'm sick listening to it.'

'You may be sick listening to it Joe, but you're doing nothing about it. Your health has run down to such a state that you're hallucinating, or maybe it was the drink. Your boss wouldn't be so proud of you if he knew you were doing that, would he?'

Joe sat with his head bowed.

'No I didn't think so. You would be out quicker than Jack Flash.'

'Look,' Joe snapped, finding his voice again. 'I do all this for you and the kids and ...'

'Don't give me that Joe,' she said with raised voice and scornful look. 'You haven't seen your kids most of the year, you couldn't even make it to one of their birthdays. How many times am I going to have to ask you for the sake of our marriage to give that job up.'

They argued for most of the weekend, both getting nowhere.

Monday morning arrived. All two hundred sales representatives of ' $\mathrm{Calco}$ ' fascia board house fronts were present in the dining hall, as was required by the management. Eleven a.m. was the deadline for the final contracts to be included in this year's tally, deciding who would be top dog. A cushion-stuffed Santa Claus and two mini-skirted helpers passed out sandwiches and drinks. Most of the reps had put their contracts in between nine and ten a.m. There were only a handful left. Protocol dictated that the five top men were last to go, in order of running from five to one. By the time Kenny Spring walked to the tally desk, there was quite a buzz of anticipation. It died down as he removed the contents of his briefcase. He held slightly aloft four contracts. The captivated audience cheered and whistled.

Joe watched the crowd applaud and yell messages of congratulations and support to Spring. His tally came up on the board, two more than Joe's. As Spring walked by him with a wry grin, they both glared at each other.

'Joe?' the girl at the tally desk said, with an outstretched hand. He looked at her hand, then slowly turned to look at the now quietened crowd. Someone popped a balloon, bringing a ripple of laughter.

'Joe?' she repeated. He felt his briefcase and stared at the crowd. Little beads of sweat glistened on his brow. One by one they started to egg him on. 'Joe, Joe, Joe, Joe.' The whole crowd seemed to be chanting in unison. 'Joe, Joe, Joe, Joe.' They were like supporters at a football match and Joe felt like the star 
of the team. He smiled at them, felt the leather-bound case once more, then in a quick jerking movement, put it on the girl's desk.

'Three,' he said.

'Did he say three?' someone in the crowd asked.

'Look's like it's Joe's,' another said.

A murmur of excitement swept the room.

He watched the girl open the case. A charred piece of paper whirled into the air. Joe watched astounded as it floated past his face. He looked to the case, his eyes widening with horror. He plunged both hands into the ashes and rummaged through it. The girl stared at him in amazement, the hushed crowd looked at each other, then to Joe. His tally went up on the board, the crowd went wild cheering, popping balloons, and throwing streamers. Spring was lifted shoulder high and carried out of the canteen. Joe, stunned, was looking into empty space when the girl at the tally desk eventually got his attention.

'Joe, Joe,' she said, tugging at his sleeve. 'The boss has just phoned. $\mathrm{He}$ wants to see you in his office right away.'

'This is Peter Bumstein,' his boss said. 'He's a very good friend of mine ... He's with the Boston P.D.'

Joe shook hands with the tall slim figure, who then turned and sat on the two seater by the wall.

'Take a seat,' his boss said, an order more than a request. His boss Karl was a burly six-foot-two of a man. He sat on the corner of his desk, the corner closest to Joe's chair, his towering frame intimidating at such close proximity. He looked down at Joe, who dropped timid eyes.

'You've been with us how long now Joseph?' He always called people by their full Christian name.

'Six years,' he replied.

'And how many of them at the top?'

'Three,' he answered proudly.

'I expected better from a man in your position.'

Joe felt his face flush. He could do without a dressing down in front of the boss' $s$ friend. 'It wasn't my fault Karl, if I ...'

'Wasn't your fault?' he said, getting off the edge of the desk. 'Wasn't your fault?' His tone was sharp. 'Well if it wasn't your fault, whose damn fault was it?'

He thought about trying to explain the charred remains of the contracts, but decided it would be better to remain silent.

'I'll be back up there next year Karl, I'll be on top of the pile again, it's just that ....' He lowered his voice to a whisper. 'It's just that I've been having a few problems at home, but I guarantee I'll be back on top next year.'

'Not with this firm you won't,' Karl said.

Joe's lower jaw dropped an inch. 'Won't be ... Won't be back?' He couldn't believe what he was hearing. 'You mean to say ... Iet me get this right,' he said, wiping the back of his hand across a sweating brow. 'You mean to say you're going to let me go because I didn't make it back to the top? What kind of ...' 
'Back to the top? What are you talking about man. Surely you know why you're in here and it has nothing to do with any tally.

Joe was puzzled for a moment, then turned to look at the slim figure sitting quietly behind him. It was only then he realised his boss's friend wasn't here for a Christmas reunion.

'Where were you on Friday night Joe, say between the hours of eight and midnight?' the policeman inquired. Joe's heart pumped a little faster now, realising he wasn't in the office for a dressing down.

'Friday night?' His thoughts went into overdrive. 'Friday night? Ah ... I, ah ... Yes!' he said, with a certain degree of relief. 'I was driving on the interstate between those hours.'

'In your own car?'

'Yes, well, in the company car,' he said with a twitching grin. He could feel a little trickle of sweat plough its way down his back.

Karl fed a video tape into the machine, the picture came up with a still photo of his car, the number plate quite clear. 'This is your car Joe?' he asked pointing to the time, date, and location record in the corner.

'Yes ... Yes it is,' he said, still puzzled.

'And by your own admission, you in it.'

No answer was given, and none expected. His boss hit the play button. Joe watched in horror as his car swerved from lane to lane cutting across other traffic. The speedometer recorded speeds at times in access of $110 \mathrm{mph}$.

'You see Joe, Peter here has agreed that seeing as no one was hurt in this madness,' he said, pointing to the screen with a pen, 'that the action I am about to take will suffice instead of lengthy legal proceedings.' The words just whirled around in Joe's head as he glared at his actions on the video.

'Even though you are one of our best reps and we are in the mouth of Christmas, I can't ignore actions such as these. There is no doubt in my mind that you must have been drinking on Friday night. You know we have a very strict policy about that. It must be quite clear to you that our company can't afford multi-car pile-ups. I'll expect your resignation on my desk by the end of business today. The rest of the staff will know nothing of this, they'll simply think you're a sore loser. By the way,' he added, as a stunned Joe walked out the door. 'You can also leave the keys of the car.'

Snow had fallen all weekend and lay thick on the branches of the tree-lined avenue. Joe arrived home in a hired cab. There was another sitting outside the house with its engine running. He wondered who it might be for. As he walked along the pathway he got his answer. Bella was coming out carrying a suitcase, with three children in tow.

'What's goi...' He knew what he wanted to say but the words wouldn't come easy, they choked their way out. 'Bella ... What's happening? What's going on?'

'Go on kids, into the cab.' She ushered them past their father, leaving fresh footprints in the virgin snow. 
'For God's sake Bella,' he said, taking her by the wrist. 'Tell me what's going on.'

She looked with cold eyes, then walked back into the house with him. 'I think it's pretty clear what's going on Joe, we're leaving.'

'What do you mean you're leaving?'

There was panic in his voice, mixed with nervous laughter, the type that makes one's own voice unrecognisable. 'I don't ... I don't understand.'

'That's the problem Joe. That has always been the problem. How often have I told you that you were a stranger to your own kids. They didn't even want to kiss you goodbye for God's sake.'

Fury didn't mix well with confusion. His eyelids half closed. He lifted a hand and slapped Bella hard on the face, something he had never done the whole time of their marriage. Her face turned with the slap. He lifted his hand to slap her again. 'Why now? why now?' he yelled.

She didn't try to cover her face but simply stared at her husband, his hand remained above his head. The sparkle of a tear appeared in her eyes caused not by pain, but at what had become of him. He crashed his hand against the door frame. They both stood a moment in awkward silence, searching each other's eyes.

'Bella forgive me please,' he said. 'Let's work this out, we can work it out. I've left my job. I'll have more time for you and the kids. Please Bella, I'll never raise a hand in anger again, you know that. I love you and the kids. Please don't go.'

She stared at him still but with eyes of pity, not love. 'It's too late Joe. You received love freely but you wouldn't give it back. It's too late,' she repeated in a whisper as a tear fell from her cheek. He didn't want to, but something made him loosen his grip on her wrist. She lifted the suitcase and walked out the door without a backward glance. He knew he had lost them.

Joe fell into his chair in the study, buried his head in his hands and cried.

'It's all going wrong. I've lost a job and a family all in one day. What have I done to deserve this?' He sobbed for some time. Self pity eventually turned to anger. Taking the bottle of whisky from the drawer he tried to open it with his right hand but it had throbbed painfully since he crashed it against the door frame. He took the bottle in his left and smashed the neck on the desk. He stretched his right hand trying to ease the pain, but the whisky eased it better. He fell into a drunken slumber.

The pain in his hand woke him some hours later. It took him a moment to focus on the empty bottle on the table. Then he lifted his hand to check the throbbing pain. Rubbing his eyes to look again, still not believing what he thought he was seeing, he turned on the table lamp. His eyes widened with shock. Before him was a hand twice its normal size and almost black. He screamed an unmerciful sound that echoed around the empty house. 'NO...! GEORGE PLEASE ... NO.' 